Chapter 3

\title{
Current Understanding of Epigenomics and Epigenetics in Neurodevelopmental Disorders
}

\author{
Takeo Kubota, Kunio Miyake and Takae Hirasawa \\ Additional information is available at the end of the chapter \\ http://dx.doi.org/10.5772/57534
}

\section{Introduction}

Epigenetics is a mechanism that regulates gene expression not depending on the underlying DNA sequence, but on the chemical modification of DNA and histone proteins. It is known that several neurodevelopmental disorders are caused by congenital abnormalities in epigenetic mechanisms, including Prader-Willi and Angelman syndromes, which are genomic imprinting disorders [1-3]. The advances in understanding of the epigenetic gene regulation mechanisms and identification of proteins that participate in them have led to the identification of other neurodevelopmental disorders, such as ICF and Rett syndromes, caused by mutations in the genes that encode such proteins [4-8]. The discovery of Rett syndrome, a representative autistic disorder caused by mutations in $M E C P 2$ that encodes an epigenetic regulatory protein, introduced to us a new paradigm that neurodevelopmental disorders are not only caused by mutations in the neuronal genes $[9,10]$, but also caused by abnormal epigenetic regulation of the neuronal genes.

Several lines of evidence suggest that various environmental factors, such as nutrition (e.g. folic acid and royal jelly), environmental chemicals, external electric stimuli to neurons, and mental stress, can change epigenomic status, which supports the hypothesis that the epigenome is more susceptible to environmental factors than the genome [11].

DNA methylation was initially believed to change gradually during the lifetime through studies in cancer. However, it has recently been shown that DNA methylation can be altered during the first week of life after birth in mice, and that the altered epigenomic status in the brain is prolonged throughout the lifetime long with abnormal behavior [12]. It is also reported that epigenetic changes can be induced by malnutrition during the fetal period, which introduces the origin of adult diseases in the fetus in rats $[13,14]$. Recent comparative studies between monozygotic twins suggest that epigenomic changes also occur in humans $[15,16]$. 
Epigenetic is a reversible mechanism and thus, it has been accepted as a mechanism for genomic imprinting in which the maternal expression pattern can be erased and reset to be the paternal expression pattern when the imprinted gene is transmitted from the mother to the offspring [17-20]. It has recently been shown that some drugs for mental disorders have an effect on restoration of the epigenetic status and the expression pattern of the neuronal genes based on this epigenomic reversibility [21-25]. It has also been reported that administration of folic acid is effective in treating autistic children possibly by restoring DNA methylation status at the disease-related gene regions [26-28]. Therefore, it is intriguing to think that advanced "epigenomic drug" can be designed that only target to disease-specific gene regions using recent technology such as pyrrole-imidazole polyamide [29, 30].

Epigenetics now challenge the biological dogma that "acquired nature cannot be transmitted to the next generation", because recent studies have shown that mental stress-induced epigenomic changes cannot be completely erased at the stage of spermatogenesis and can be transmitted to the third generation in mice [20,31]. However, it is possible that appropriate intervention such as drug, nutrition, and environmental condition can be restore the abnormal epigenomic status and halt its inheritance, if such transmission is true in humans.

In this chapter, we present the epigenetic mechanisms that cause congenital disorders, show examples of environmental factors that can alter the epigenetic status, and discuss recent topics in epigenetics, such as strategies for the treatment of neurodevelopmental disorders utilizing epigenetic reversibility and the possibility of its transgenerational inheritance.

\section{Importance of proper gene regulation in the brain}

The brain is a gene-dosage sensitive organ in which either under-expression or over-expression of the same genes encoding proteins related to brain function results in a range of neurological disorders. For example, Pelizaeus-Merzbacher disease, a severe congenital disease is caused by either a deletion, mutation, or duplication of the proteolipid protein 1 (PLP1) gene [32]. Further, lissencephaly, a rare brain formation disorder, is caused by either deletion or duplication of the platelet-activating factor acetylhydrolase 1B subunit alpha (PAFAH1B1) gene that encodes a neuronal migration factor $[33,34]$. Charcot-Marie-Tooth disease, an adult-onset neuromuscular disease is caused by a mutation or duplication of the peripheral myelin protein 22 (PMP22) gene [35], and Parkinson's disease is caused by a mutation or multiplication of the $\alpha$-synuclein (SNCA) gene [36]. These are all neurological disorders, and such examples have not been observed in other clinical fields. Thus, these findings suggest that the brain is extremely sensitive to perturbations in gene regulation, and further indicate that the brain is an organ that requires a proper control system for gene expression.

Epigenetic mechanisms are one of the ways by which gene expression is controlled in higher vertebrates. These mechanisms are essential for normal development during embryogenesis [37], and for differentiation of neural cells [38] and other cell types [39]. Understanding of epigenetic mechanisms, including DNA methylation, histone modification, and regulation by 
microRNAs, is important in elucidating the pathogenic pathways in neurodevelopmental disorders [40-42].

\section{Epigenetic mechanisms that cause congenital neurodevelopmental disorders}

Genomic imprinting is an epigenetic phenomenon that was initially discovered in humans and mammals, which determines parental-specific monoallelic expression of a relatively small number of genes during development. Imprinting must be logically imparted in the germ line, where inherited maternal and paternal imprints are erased and new imprinting established according to the individual's sex (Figure 1) [17]. For example, before the maternal allele-specific DNA methylation that contribute to monoallelic expression is established in a differential methylated region 2 (DMR2) of mouse Igf2 gene, DMR2 is demethylated in both male and female primordial gene cells (PGCs) by 13.5 days post coitum (dpc), indicating that the erasure of imprinting in this region occurs earlier in PGC development [18]. Although DNA methylation is the best established epigenetic mark that is critical for the allele-specific expression of imprinted genes, many aspects of the regulation of DNA methylation are unknown, including how methylation complexes are targeted and the molecular mechanisms underlying DNA demethylation [19]. In this context, one mechanism related to genome-wide DNA demethylation to reset the epigenome for totipotency was recently revealed that erasure of $\mathrm{CpG}$ methylation (5mC) in PGCs occurs via conversion to 5-hydroxymethylcytosine ( $5 \mathrm{hmC}$ ), driven by high levels of TET1 and TET2, and that global conversion to $5 \mathrm{hmC}$ is initiated asynchronously in PGCs at embryonic days (E) 9.5 to E10.5 for imprint erasure [20].

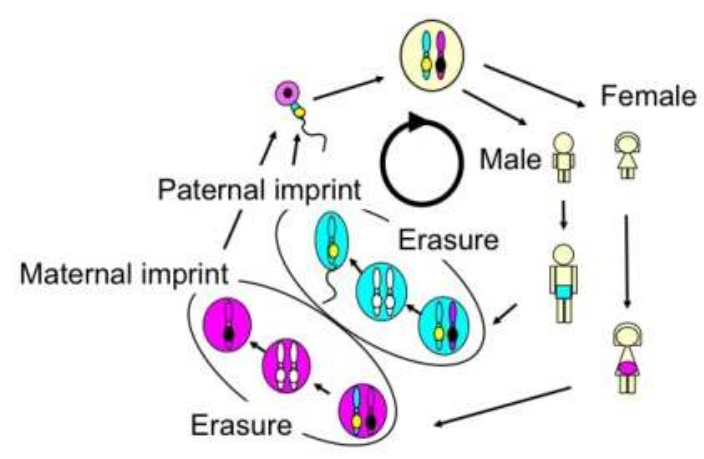

Figure 1. Erasure and establishment of genomic imprinting. Inherited maternal and paternal imprints are erased and new imprinting established according to the individual's sex during the process of spermatogenesis and oogenesis.

In an imprinted gene, one of the two parental alleles is active and the other is inactive due to an epigenetic mechanism such as DNA methylation. Therefore, a defect in the active allele of the imprinted gene results in the loss of expression. This has been found in the neurodevelopmental diseases, Prader-Willi syndrome and Angelman syndrome [2]. 
The $\mathrm{X}$ chromosome has a large number of genes, whereas the $\mathrm{Y}$ chromosome has relatively few. Thus, females $(X X)$ have more genes than males (XY). To minimize this sex imbalance, one of the two $X$ chromosomes in females is inactivated by an epigenetic mechanism [3]. Improper $\mathrm{X}$ chromosome inactivation $(\mathrm{XCI})$ is thought to be an embryonic lethal condition, as suggested by the findings that a majority of aborted embryonic clones produced by somatic nuclear transfer showed failure of XCI $[43,44]$, although it is difficult to directly demonstrate failure of XCI in human aborted embryos. Even when failure of XCI occurs in women with one normal $X$ chromosome and a small $X$ chromosome due to a large terminal deletion, and thus the overdosage effect of $X$-linked genes is small, such affected women show severe congenital neurodevelopmental delays [3], indicating that proper epigenetic gene suppression is essential for normal development.

DNA methylation is a fundamental step in epigenetic gene control, and occurs by the DNA methyltransferase (DNMT)-mediated addition of a methyl group $\left(\mathrm{CH}_{3}\right)$ to $\mathrm{CpG}$ dinucleotides. A defect in one of the DNMTs (e.g., DNMT3B) can cause a syndrome characterized by immunodeficiency, centromere instability, facial anomalies (ICF), and mild mental retardation [4-6]. Methyl-CpG-binding domain proteins (MBDs) are also important molecules in the control of gene expression. Mutations in the methyl-CpG-binding protein 2 gene (MECP2), one of the genes that encodes for MBD protein, can cause Rett syndrome, which is characterized by seizures, ataxic gait, language dysfunction, and autistic behavior [7, 8]. Therefore, it is thought that MeCP2 dysfunction leads to aberrant expression of genes in the brain associated with neurological features of the disease. Recent studies have shown that MeCP2 controls a subset of neuronal genes [45-48] or a potentially large number of genes [49], suggesting that epigenetic dysregulation of multiple neuronal genes may cause neurological features of the disease.

\section{Environmental factors that alter the epigenetic status associated with neurodevelopmental disorders}

We have previously demonstrated that epigenetic instability at imprinting loci during the process of finding proper methylation sites for diagnosis of Prader-Willi / Angelman syndromes, the epigenetic disorders described above [50]. In our study, the imprinted DNA methylation status at the small nuclear ribonucleoprotein associated polypeptide $\mathrm{N}$ (SNRPN) promoter region (e.g., maternally methylated and paternally unmethylated) in chromosome 15 q12 was stable among various tissues such as lymphocyte, amniotic fluid cells, cultured chorionic villus samples, various fetal tissues and Epstein-Barr virus lymphoblast cell lines established from lymphocytes. However, at the PW71 locus adjacent to the SNRPN locus, the imprinted methylation status was not consistent among these tissues. This indicates that epigenetic status at the loci associated with neurodevelopmental disorders are susceptible to environmental factors in vitro.

In neurodevelopmental disorders such as autism, both environmental factors (e.g., toxins, infections) and genetic factors (e.g., mutations in synaptic molecules) have historically been 
discussed [51]. However, a biological mechanism that links these two groups of factors has not been identified. Epigenetics may be the bridge between these factors, thereby contributing to disease development [11]. Besides the intrinsic (congenital) epigenetic defects (associated with disease as described above), several lines of evidence suggest that extrinsic (environmental) factors, such as malnutrition [13, 14], drugs [21-25], mental stress during the neonatal period [12], and neuronal stimulation [52], alter the epigenetic status and thereby affect brain function. Therefore, it is intriguing to speculate that acquired neurodevelopmental disorders, including autistic disorders, may be the result of epigenetic dysregulation caused by environmental factors (Figure 2).

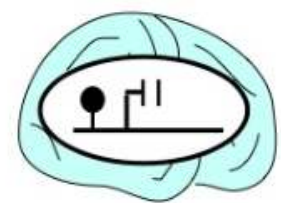

Environmental factors

- Malnutrition

- Drugs (side effect)

- Chemicals

- Mental stress
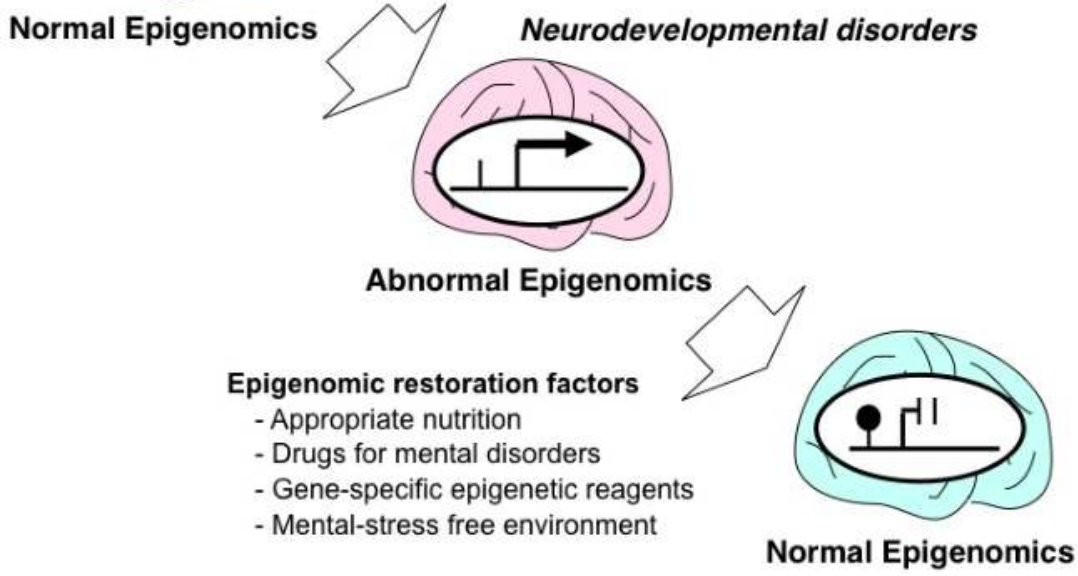

Figure 2. Current understanding of extrinsic mechanisms of neurodevelopmental disorders. Acquired neurodevelopmental disorders are caused by extrinsic mechanism via various environmental factors.

Short-term mental stress after birth may alter the epigenetic status in the brain and result in persistent abnormal behavior [12]. In rat pups from mothers exhibiting low levels of maternal care, DNA methylation at the promoter of the glucocorticoid receptor gene (GR), which is also known as the nuclear receptor subfamily 3 group C member 1 (NR3C1) gene, increased in the hippocampus, which suppressed expression of the gene within the first week of life. In contrast, promoter methylation decreased in the brains of the offspring with high maternal care during the same period [12]. This paradigm was suggested to provide a putative animal model for childhood neglect and maltreatment in humans. Postmortem analysis of the hippocampus of suicide victims with a history of childhood abuse revealed the presence of hypermethylation of the neuron-specific promoter of NR3C1 in combination with a decrease in its expression [53]. 
This finding suggests that the adverse effects of early-life stress on DNA methylation may last throughout life [54], and also indicates that neurodevelopmental problems may arise from epigenetic dysregulation caused by environmental factors in early life.

Epigenetic mechanisms are also likely to be relevant to drug addiction. Gene expression in the dopaminergic and glutamatergic systems is mediated by epigenetic mechanisms, and cocaine and alcohol are known to alter the epigenetic state (e.g., cocaine induces either hyperacetylation or hypoacetylation of histone $\mathrm{H} 3$ or $\mathrm{H} 4$ in the nucleus accumbens of mice, and alcohol induces hyperacetylation of histones $\mathrm{H} 3$ and $\mathrm{H} 4$ in the frontal cortex and the nucleus accumbens of adolescent rats), which may be associated with permanent behavioral consequences $[55,56]$.

The findings above were mainly obtained in animal studies, and there is little evidence in humans. However, the fact that epigenomic differences are larger in older monozygotic twins than those in younger twins suggests that epigenetic status may be altered during aging by environmental factors in humans [15]. Likewise, in monozygotic twins with discordant severity of Rett syndrome, the epigenomic patterns and expression of neuronal genes have been shown to differ [16]. This indicates that environmental factors may affect the human epigenome and that epigenomic differences induced by environmental factors may contribute to mental phenotypes.

Another phenomenon that may be related to epigenomic changes is the decline in birth weights that has occurred during the past 20 years. This trend is thought to be a result of the popularity of dieting among young women and of the recommendation by obstetric physicians to minimize pregnancy weight gain in order to reduce the risk of gestational diabetes mellitus [57]. Based on current epidemiological studies of populations affected by famines in the Netherlands and China, the generation with lower birth weight is expected to have an increased risk of not only metabolic disorders (e.g., obesity, diabetes mellitus) [58], but also mental disorders [59]. This expectation is referred to as the Developmental Origin of Health and Diseases (DOHaD) [60]. Recent studies have demonstrated that malnutrition during the fetal period causes a hypomethylation imprint on the peroxisome proliferator-activated receptor alpha (PPARa) gene in the rat liver [61]. Similar DNA methylation changes have been identified in the peripheral tissues of people who suffered malnutrition during a period of famine in the Netherlands [62]. It has also been reported that assisted reproductive technologies (ART) (e.g., in vitro fertilization and intracytoplasmic sperm injection), which are now widely used due to increases in maternal age, lead to decreased DNA methylation status at multiple maternally methylated imprinted loci $[63,64]$. Therefore, it is intriguing to think that current social factors, such as DOHaD and ART, may be involved in the recent increase of children with mild neurodevelopmental disorders in Japan and other countries [65-70] and that epigenetic alteration may underlie this social phenomenon. 


\section{Treatment of neurodevelopmental disorders by utilizing epigenetic reversibility}

It has been reported that administration of folic acid to pregnant rats alters the DNA methylation status in the offspring [71]. Furthermore, folic acid supplementation in pregnant rats under malnutrition conditions prevents hypomethylation of a hepatic gene in the offspring [13]. In addition to folic acid, various environmental factors, such as royal jelly [72], drugs for mental disorders [21, 23, 25], environmental chemicals [73, 74], and external stimuli (electroconvulsive treatment for psychiatric diseases) [49], have also been reported to alter DNA methylation and histone modification status in the brain and other organs in mice or other species.

As mentioned above, mental stress in the first week of life causes epigenetic abnormalities in the brains of mice. Conversely, several mouse studies have demonstrated that appropriate educational conditions can ameliorate behavior abnormalities. Environmental enrichment (EE), consisting of larger-sized home cages with a variety of objects including running wheels, improved motor coordination and decreased anxiety-related behavior in heterozygous Mecp2+/-female mice, a model of Rett syndrome [75, 76]. EE also improved locomotor activity with reduced ventricular volume, and restored the expression of synaptic markers, such as synaptophysin and PSD95 in the hypothalamus and syntaxin 1a and synaptotagmin in the cortex of hemizygous Mecp2-/y male mice [77, 78].

It is generally thought to be difficult to cure patients with congenital mental disorders caused by mutations that encode neuronal molecules, since it is difficult to distribute gene products to the appropriate brain regions and at the appropriate time of brain development. However, it was recently demonstrated that the epigenetic disorder Rett syndrome may be an exception, partly because $\mathrm{MeCP} 2$ does not encode a product required for brain structure, but rather encodes a "lubricant" that works at a relatively later period of brain development. As a consequence, reintroduction of MECP2 into Mecp2 null mice not only before birth [79], but also after birth, is sufficient to rescue Rett-like neurological symptoms [80]. Furthermore, restoration of MeCP2 function in astrocytes substantially improves locomotion, anxiety levels, and respiratory abnormalities in hemizygous Mecp2-/Y male mice along with restoring dendritic morphology [81]. These results suggest that up-regulation of $M E C P 2$, possibly mediated by drug treatment, might help to improve brain function in Rett syndrome patients. Valproic acid, one of the most popular drugs for epileptic seizure and a known HDAC inhibitor, increases MeCP2 expression [82, 83], as well as fluoxetine, a drug for mental disorders, and cocaine [84]. Taken together, these results indicate that neurodevelopmental disorders caused by epigenetic abnormalities can be treatable.

\section{The possibility of transgenerational epigenetic inheritance}

According to current understanding in the field of biology, one's acquired character is not inherited by the next generation of offspring. Based on this notion of Darwinian inheritance, 
bad habits acquired during one's lifetime would not be transmitted to one's children. However, recent advances in epigenomics and epigenetics have revealed that such undesirable acquired traits might be transmitted into the next generation.

Epigenetic marks, either DNA methylation or histone modifications, allow the mitotic transmission of gene activity states from one cell to its daughter cells. A fundamental question in epigenetics is whether these marks can also be transmitted meiotically through the germline. In mammals, epigenetic marks should be cleared by demethylating factors such as the cytidine deaminases (e.g., AID, APOBEC1) and re-established in each generation, but this clearing is incomplete at some loci in the genome of several model organisms possibly due to deficiency of demethylating factors (e.g. AID) [85]. A recent study has demonstrated rare regulatory elements that escape systematic DNA demethylation in PGCs, providing a potential mechanistic basis for transgenerational epigenetic inheritance [20]. Therefore, based on this phenomenon, "transgenerational epigenetic inheritance", which refers to the germline transmission of an epigenetic mark [86, 87], may provide a direct biological proof for Lamarckism, hypothesis suggesting the heritability of acquired characteristics.

It is important to draw a distinction between transgenerational epigenetic inheritance and heritable germline epimutation. Transgenerational epigenetic inheritance is independent of the DNA sequence, whereas heritable germline epimutation is a direct consequence of a cisacting epigenetic alteration, such as hypermethylation induced by an expansion of an unstable CGG repeat within exon 1 of the Fragile X Mental Retardation Syndrome 1 gene (FMR1), hypermethylation induced by a deletion in an adjacent gene within the promoter of the globin gene, and hypermethylation induced by repetitive retrotransposons [87, 88]. Such specificsequence driven-epimutation is observed in an affected mother and son in a family with fragile $\mathrm{X}$ syndrome, and it can be classified as a case of heritable germline epimutation [88]. This inheritance pattern is also observed in other species, such as Caenorhabditis elegans. Therefore, the heritability does not necessarily involve transgenerational epigenetic inheritance, as the methylated state could be cleared on passage through the germline and could be re-established according to a certain sequence during zygotic genome activation [88].

Transgenerational inheritance of epigenetic marks was first demonstrated in a specific mouse strain. The methylation status at the Axin ( $F u$ ) locus in mature sperm, which reflects the methylation state of the allele in the somatic tissue of the animal is linked to the shape of the animal's tail and does not undergo epigenetic reprogramming during gametogenesis [89]. Environmental factors, notably the fungicide vinclozilin, stress responses and nutritional challenges, have been associated with transgenerational epigenetic inheritance in animal models. However, it is often difficult to obtain direct evidence of transmission of epigenetic marks per se from transmission of the exposure itself [90, 91]. Therefore, transgenerational effects should be distinguished from parental and grandparental effects. In addition to contributing to their DNA, parents can influence their offspring in many ways: for example, by contributing bioactive molecules in the egg and sperm cytoplasm, and by providing nutrients and hormonal information during embyogenesis. For example, malnutrition during pregnancy does not only affect the pregnant mother and fetus but also the fetus's primordial germ cells, which can lead to phenotypic changes in the grandchildren (second generation). 
In one study, a specific diet (supplementation of folic acid) induced methylation at the Axin $\mathrm{Fu}$ locus, which altered the hair color of the animals, and this alteration was inherited over 2 generations, but this status was lost by the third generation [92]. These findings indicate that while a specific diet leads to parental and grandparental effects, the acquired epigenetic information is not inherited transgenerationally, and that the Axin (Fu) locus is resistant to environmentally induced acquisition of new germ-line epigenetic information [92].

Transgenerational effects of environmental toxins - namely, the endocrine disruptors vinclozolin (an antiandrogenic compound) and methyoxychlor (estrogenic compound)-have been demonstrated in the fourth generation (F4) of rats resulting in decreased spermatogenic capacity and increased male infertility, and the effects on reproduction correlate with altered DNA methylation patterns in the germ line [93]. It has also been demonstrated that plasticderived endocrine disrupters, including bisphenol A, increase the risk of pubertal abnormalities, testicular diseases and ovarian diseases in the F3 generation of rats, and that differential DNA methylated patterns were identified in the plastic-lineage F3 generation sperm in comparison with control-lineage F3 generation sperm [94]. Therefore, "true" transgenerational epigenetic inheritance up to third generation is suggested to exist in animals. This observation has also been confirmed in Drosophila, in which an aberrant epigenetic mark (defective chromatin state) acquired in one generation induced by environmental stress (e.g. heat shock) was inherited by the next generation [95].

It has also been demonstrated that an aberrant epigenetic mark acquired in one generation by mental stress (maternal separation in early life) can be inherited by the next generation (Figure 3, left) [31]. Chronic maternal separation alters behaviors as well as the profile of DNA methylation in the promoter of several candidate genes in both the germline of the separated mice and brains of the offspring with altered gene expression (e.g. decreases in the expression of corticotropin releasing factor receptor $2(\mathrm{Cr} f \mathrm{r} 2)$ in the amygdala and the hypothalamus) [31]. In this study, abnormal behavior was observed in the third generation, and altered DNA methylation in the CpG islands of Mecp2, cannabinoid receptor-1 (Cb1), and Crfr2 were observed in F1 sperm and F2 brain. It has also been reported that chronic maternal separation increases cytosine methylation of the estrogen receptor (Er)-alpha1b gene promoter, indicating that individual differences in maternal behavior are epigenetically transmitted from the mother to her female offspring [96]. Further, the third generation of male rats upon exposure to vinclozolin, a commonly-used fungicide, respond differently to chronic restraint (i.e., mental) stress during adolescence; they also show altered gene expression in the cortex and CA1 regions of the brain, although direct epigenetic alteration (e.g., DNA methylation) has not been confirmed [97]. These findings provide biological evidence suggesting that environmental factors, including traumatic experiences in early life, are risk factors for the development of behavioral and emotional disorders.

Environmental stress (e.g., maternal separation) in neonatal period induces epigenomic changes in the brain and sperm in mice. The changes are transmitted to the next generation along with abnormal behavior even when the offspring is reared by a normal mother. However, it is possible to ameliorate these epigenetic changes by providing appropriate environ- 


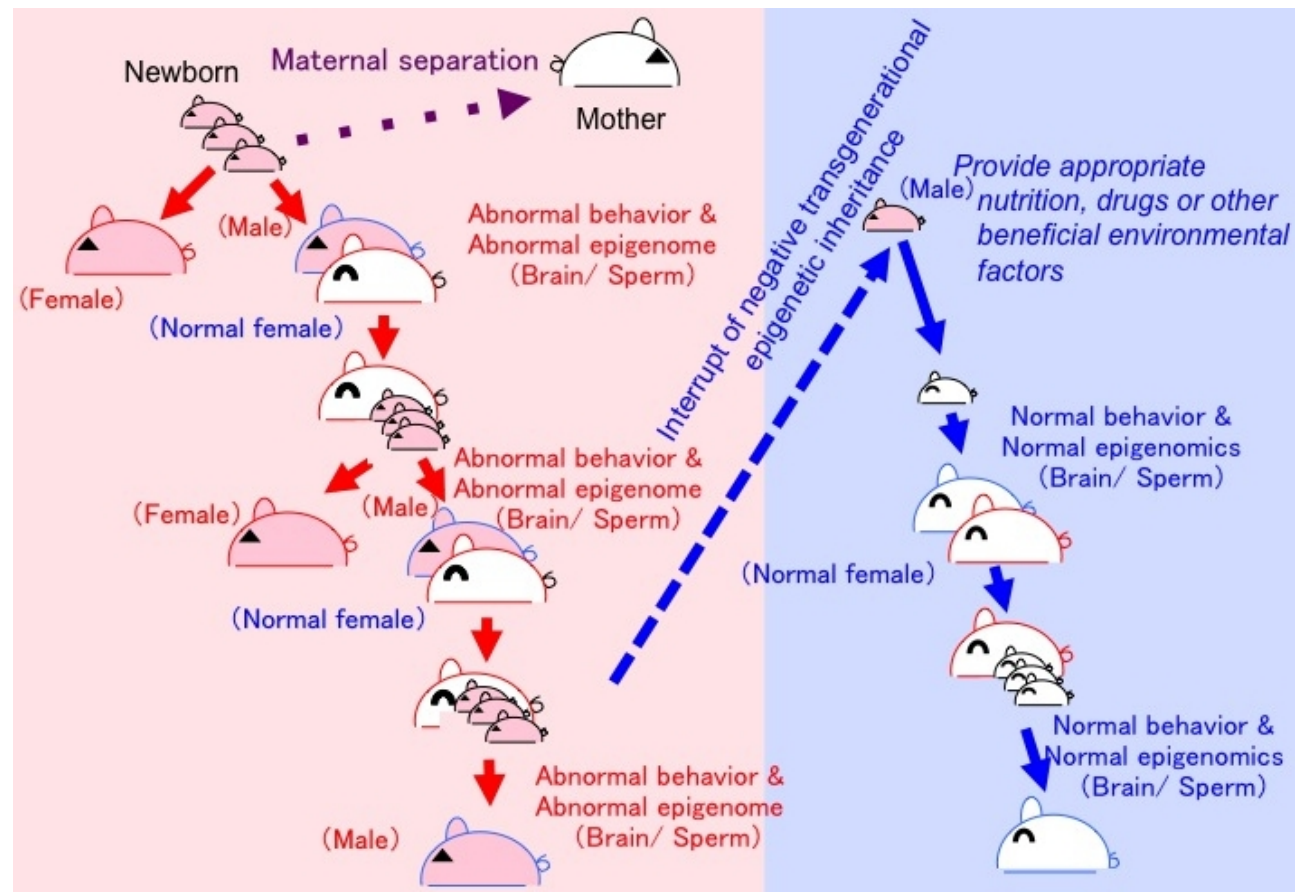

Figure 3. Transgenerational abnormal epigenomic inheritance along with abnormal phenotype.

mental factors (e.g., nutrition, neuropsychiatric drugs or brain-stimulating enriched environment).

Recent studies have suggested that epigenetic variations influenced by the environment occur spontaneously and that the specific epigenetic pattern created is inherited over several generations in plant populations. Understanding the emergence and heritability of epigenetic variants is critical for understanding how they might become subject to natural selection and thus affect genetic diversity [98]. In humans, clinical features can vary among family members who share the same disease-causing mutation-a phenomenon referred to as variable expressivity; however, the precise molecular mechanism is not known. Therefore, it is intriguing to speculate that the variable clinical expressivity is caused by the stochastic occurrence of epigenetic variation during development [99] or by the spontaneous epigenetic changes during the transmission to the next generation, as was observed in plants $[98,100]$.

It has been demonstrated that neuronal plasticity is determined by epigenetic plasticity, such as chromatin remodeling and dynamic DNA methylation changes during brain development $[101,102]$, and multiple lines of evidence that connect environmental factors to brain functions via epigenetic regulation have been accumulating [21-25]. However, little is known as to whether environment-induced epigenetic changes in the brain are transmitted to the next generation along with abnormal brain functions, including mental disorders [31, 103]. 
In this context, whereas it is widely known that maternal nutrition and metabolism are critical determinants of adult offspring health, recent reports describe adverse offspring outcomes associated with the father's diet, indicating nongenetic inheritance of paternal experience [104]. Since the results of this study were interpreted as "you are what your dad ate" [105], we may be able to interpret the results of studies of transgenerational epigenetic inheritance associated with a specific mental state [31, 103] as "you are how your dad behaved". Determining the underlying mechanisms may require a reevaluation of our understanding of the heritability of epigenetic states.

Based on the evidence described above, the readers of this chapter might draw the conclusion that the field of epigenetics portends adverse news for society. However, if we are able to identify a beneficial environment for human health in terms of epigenetics, it may be possible to sever the environment-induced epigenetic patterns across the generation. Epigenetic markings provide a "memory of past experiences"; these markings persist during the life span of an individual and are transmitted to the offspring. Recent reports indicate that epigenetic marks are a "memory of past experiences" that can be restored by taking advantage of the reversibility of epigenetic modifications [106, 107]. Therefore, drug discovery and identification of beneficial condition to revert abnormal epigenetic modification may make it possible to interrupt the negative chain reaction of transgenerational epigenetic inheritance and promote better health in future generations (Figure 3, right).

\section{Conclusion}

The failure of epigenetic gene regulation is known to cause various rare congenital disorders. However, this deregulation also cause common diseases that are induced by environmental factors, since the epigenetic status is affected and changed by various environmental factors. Furthermore, the altered epigenetic status in the genome can be transmitted to the succeeding generations. Therefore, precise understanding of gene-environment interactions in light of epigenomics and epigenetics is necessary, which will further our knowledge of neurodevelopmental disorders.

\section{Acknowledgements}

The research described in this chapter was partially supported by the Ministry of Education, Science, Sports and Culture (MEXT), Grants-in-Aid (KAKENHI) for Scientific Research (A) and (B) (\#23390272; to TK), for Exploratory Research (\#25670473; to TK), for Young Scientists (B) (\#25860852; to KM), for Grant-in-Aid for Scientific Research on Innovative Areas "Genome Science" (to TK), for Scientific Research (C) (\#23591491; to TH). 


\section{Author details}

Takeo Kubota*, Kunio Miyake and Takae Hirasawa

*Address all correspondence to: takeot@yamanashi.ac.jp

Department of Epigenetics Medicine, Interdisciplinary Graduate School of Medicine and Engineering, University of Yamanashi, Yamanashi, Shimokato, Chuo, Yamanashi, Japan

\section{References}

[1] Glenn CC, Porter KA, Jong MT, Nicholls RD, Driscoll DJ. Functional imprinting and epigenetic modification of the human SNRPN gene. Hum Mol Genet 1993:2(12): 2001-5.

[2] Kubota T, Das S, Christian SL, Baylin SB, Herman JG, Ledbetter DH. Methylationspecific PCR simplifies imprinting analysis. Nat Genet 1997;16(1):16-7.

[3] Kubota T, Wakui K, Nakamura T, Ohashi H, Watanabe Y, Yoshino M, Kida T, Okamoto N, Matsumura M, Muroya K, Ogata T, Goto Y, Fukushima Y. Proportion of the cells with functional $X$ disomy is associated with the severity of mental retardation in mosaic ring X Turner syndrome females. Cytogenet Genome Res 2002;99(1-4):276-84.

[4] Okano M, Bell DW, Haber DA, Li E. DNA methyltransferases Dnmt3a and Dnmt3b are essential for de novo methylation and mammalian development. Cell 1999;99(3): 247-57.

[5] Shirohzu H, Kubota T, Kumazawa A, Sado T, Chijiwa T, Inagaki K, Suetake I, Tajima S, Wakui K, Miki Y, Hayashi M, Fukushima Y, Sasaki H. Three novel DNMT3B mutations in Japanese patients with ICF syndrome. Am J Med Genet 2002;112(1):31-7.

[6] Kubota T, Furuumi H, Kamoda T, Iwasaki N, Tobita N, Fujiwara N, Goto Y, Matsui A, Sasaki H, Kajii T. ICF syndrome in a girl with DNA hypomethylation but without detectable DNMT3B mutation. Am J Med Genet A 2004;129A(3):290-3.

[7] Amir RE, Van den Veyver IB, Wan M, Tran CQ, Francke U, Zoghbi HY. Rett syndrome is caused by mutations in X-linked MECP2 encoding methyl-CpG-binding protein 2. Nat Genet 1999;23(2):185-8.

[8] Chunshu Y, Endoh K, Soutome M, Kawamura R, Kubota T. A patient with classic Rett syndrome with a novel mutation in MECP2 exon 1. Clin Genet 2006;70(6):530-1.

[9] Zoghbi HY. Postnatal neurodevelopmental disorders: meeting at the synapse? Science 2003;302(5646):826-30. 
[10] Persico AM, Bourgeron T. Searching for ways out of the autism maze: genetic, epigenetic and environmental clues. Trends Neurosci 2006; 29(7):349-58.

[11] Qiu J. Epigenetics: unfinished symphony. Nature 2006;441(7090):143-5.

[12] Weaver IC, Cervoni N, Champagne FA, D'Alessio AC, Sharma S, Seckl JR, Dymov S, Szyf M, Meaney MJ. Epigenetic programming by maternal behavior. Nat Neurosci 2004:7(8):847-54.

[13] Lillycrop KA, Phillips ES, Jackson AA, Hanson MA, Burdge GC. Dietary protein restriction of pregnant rats induces and folic acid supplementation prevents epigenetic modification of hepatic gene expression in the offspring. J Nutr 2005;135(6):1382-6.

[14] Lillycrop KA, Phillips ES, Torrens C, Hanson MA, Jackson AA, Burdge GC. Feeding pregnant rats a protein-restricted diet persistently alters the methylation of specific cytosines in the hepatic PPAR alpha promoter of the offspring. Br J Nutr 2008;100(2): 278-282.

[15] Fraga MF, Ballestar E, Paz MF, Ropero S, Setien F, Ballestar ML, Heine-Suñer D, Cigudosa JC, Urioste M, Benitez J, Boix-Chornet M, Sanchez-Aguilera A, Ling C, Carlsson E, Poulsen P, Vaag A, Stephan Z, Spector TD, Wu YZ, Plass C, Esteller M.Epigenetic differences arise during the lifetime of monozygotic twins. Proc Natl Acad Sci USA 2005;102(30):10604-9.

[16] Miyake K, Yang C, Minakuchi Y, Ohori K, Soutome M, Hirasawa T, Kazuki Y, Adachi N, Suzuki S, Itoh M, Goto YI, Andoh T, Kurosawa H, Oshimura M, Sasaki M, Toyoda A, Kubota T.Comparison of genomic and epigenomic expression in monozygotic twins discordant for Rett syndrome. PLoS ONE 8(6):e66729, 2013.

[17] Szabó PE, Mann JR. Biallelic expression of imprinted genes in the mouse germ line: implications for erasure, establishment, and mechanisms of genomic imprinting. Genes Dev 1995;9(15):1857-68.

[18] Sato S, Yoshimizu T, Sato E, Matsui Y. Erasure of methylation imprinting of Igf2r during mouse primordial germ-cell development. Mol Reprod Dev 2003;65(1):41-50.

[19] Weaver JR, Susiarjo M, Bartolomei MS. Imprinting and epigenetic changes in the early embryo. Mamm Genome 2009;20(9-10):532-43.

[20] Hackett JA, Sengupta R, Zylicz JJ, Murakami K, Lee C, Down TA, Surani MA. Germline DNA demethylation dynamics and imprint erasure through 5-hydroxymethylcytosine.Science. 2013;339(6118):448-52.

[21] Tsankova NM, Berton O, Renthal W, Kumar A, Neve RL, Nestler EJ. Sustained hippocampal chromatin regulation in a mouse model of depression and antidepressant action. Nat Neurosci 2006;9(4):519-25. 
[22] Jessberger S, Nakashima K, Clemenson GD Jr, Mejia E, Mathews E, Ure K, Ogawa S, Sinton CM, Gage FH, Hsieh J.Epigenetic Modulation of Seizure-Induced Neurogenesis and Cognitive Decline. J Neurosci 2007;27(22):5967-75.

[23] Dong E, Nelson M, Grayson DR, Costa E, Guidotti A. Clozapine and sulpiride but not haloperidol or olanzapine activate brain DNA demethylation. Proc Natl Acad Sci USA 2008;105(36):13614-9.

[24] Dong E, Chen Y, Gavin DP, Grayson DR, Guidotti A. Valproate induces DNA demethylation in nuclear extracts from adult mouse brain. Epigenetics 2010;5(8):730-5.

[25] Wang Q, Xu X, Li J, Liu J, Gu H, Zhang R, Chen J, Kuang Y, Fei J, Jiang C, Wang P, Pei D, Ding S, Xie X. Lithium, an anti-psychotic drug, greatly enhances the generation of induced pluripotent stem cells. Cell Res 2011;21(19):1424-35.

[26] Rimland, B. Controversies in the treatment of autistic children: vitamin and drug therapy. J Child Neurol 1988;3 Suppl, S68-S72.

[27] James SJ, Cutler P, Melnyk S, Jernigan S, Janak L, Gaylor DW, Neubrander JA. Metabolic biomarkers of increased oxidative stress and impaired methylation capacity in children with autism. Am. J. Clin. Nutr. 2004;80(6):1611-7.

[28] Moretti P, Sahoo T, Hyland K, Bottiglieri T, Peters S, del Gaudio D, Roa B, Curry S, Zhu H, Finnell RH, Neul JL, Ramaekers VT, Blau N, Bacino CA, Miller G, Scaglia F. Cerebral folate deficiency with developmental delay; autism; and response to folinic acid. Neurology 2005;64(6):1088-90.

[29] Ohtsuki A, Kimura MT, Minoshima M, Suzuki T, Ikeda M, Bando T, Nagase H, Shinohara, K, Sugiyama H. Synthesis and properties of PI polyamide-SAHA conjugate. Tetrahedron Lett 2009;50:7288-92.

[30] Matsuda H, Fukuda N, Ueno T, Katakawa M, Wang X, Watanabe T, Matsui S, Aoyama T, Saito K, Bando T, Matsumoto Y, Nagase H, Matsumoto K, Sugiyama H: Transcriptional inhibition of progressive renal disease by gene silencing pyrroleimidazole polyamide targeting of the transforming growth factor- $\beta 1$ promoter. Kidney Int 2011;79(1):46-56.

[31] Franklin TB, Russig H, Weiss IC, Gräff J, Linder N, Michalon A, Vizi S, Mansuy IM. Epigenetic transmission of the impact of early stress across generations. Biol Psychiatry 2010;68(5):408-15.

[32] Inoue K, Kanai M, Tanabe Y, Kubota T, Kashork CD, Wakui K, Fukushima Y, Lupski JR, Shaffer LG. Prenatal interphase FISH diagnosis of PLP1 duplication associated with Pelizaeus-Merzbacher disease. Prenat Diagn 2001;21(13):1133-6.

[33] Reiner O, Carrozzo R, Shen Y, Wehnert M, Faustinella F, Dobyns WB, Caskey CT, Ledbetter DH. Isolation of a Miller-Dieker lissencephaly gene containing G protein beta-subunit-like repeats. Nature 1993;364(6439):717-21. 
[34] Bi W, Sapir T, Shchelochkov OA, Zhang F, Withers MA, Hunter JV, Levy T, Shinder V, Peiffer DA, Gunderson KL, Nezarati MM, Shotts VA, Amato SS, Savage SK, Harris DJ, Day-Salvatore DL, Horner M, Lu XY, Sahoo T, Yanagawa Y, Beaudet AL, Cheung SW, Martinez S, Lupski JR, Reiner O. Increased LIS1 expression affects human and mouse brain development. Nat Genet 2009;41(2):168-77.

[35] Online Mendelian Inheritance in Man (OMIM): \#118220 http://www ncbi nlm nih gov/entrez/

[36] Obi T, Nishioka K, Ross OA, Terada T, Yamazaki K, Sugiura A, Takanashi M, Mizoguchi K, Mori H, Mizuno Y, Hattori N. Clinicopathologic study of a SNCA gene duplication patient with Parkinson disease and dementia. Neurology 2008;70(3):238-41.

[37] Li E, Beard C, Jaenisch R. Role for DNA methylation in genomic imprinting. Nature 1993;366(6453):362-5.

[38] Takizawa T, Nakashima K, Namihira M, Ochiai W, Uemura A, Yanagisawa M, Fujita N, Nakao M, Taga T. DNA methylation is a critical cell-intrinsic determinant of astrocyte differentiation in the fetal brain. Dev Cell 2001;1(6):749-758.

[39] Sakashita K, Koike K, Kinoshita T, Shiohara M, Kamijo T, Taniguchi S, Kubota T: Dynamic DNA methylation change in the CpG island region of p15 during human myeloid development. J Clin Invest 2001;108(8):1195-204.

[40] Abel T and Zukin RS. Epigenetic targets of HDAC inhibition in neurodegenerative and psychiatric disorders. Curr Opin Pharmacol 2008;8(1):57-64.

[41] Urdinguio RG, Sanchez-Mut JV, Esteller M. Epigenetic mechanisms in neurological diseases: genes syndromes and therapies: Lancet Neurol 2009;8(11):1056-72.

[42] Wu H, Tao J, Chen PJ, Shahab A, Ge W, Hart RP, Ruan X, Ruan Y, Sun YE. Genomewide analysis reveals methyl-CpG-binding protein 2-dependent regulation of microRNAs in a mouse model of Rett syndrome. Proc Natl Acad Sci U S A 2010;107(42): 18161-6.

[43] Xue F, Tian XC, Du F, Kubota C, Taneja M, Dinnyes A, Dai Y, Levine H, Pereira LV, Yang $X$. Aberrant patterns of $X$ chromosome inactivation in bovine clones. Nat Genet 2002:31(2):216-220.

[44] Nolen LD, Gao S, Han Z, Mann MR, Gie Chung Y, Otte AP, Bartolomei MS, Latham KE. $X$ chromosome reactivation and regulation in cloned embryos. Dev Biol 2005;279(2):525-540.

[45] Chen WG, Chang Q, Lin Y, Meissner A, West AE, Griffith EC, Jaenisch R, Greenberg MEDerepression of BDNF transcription involves calcium-dependent phosphorylation of MeCP2. Science 2003:302(5564):885-9. 
[46] Martinowich K, Hattori D, Wu H, Fouse S, He F, Hu Y, Fan G, Sun YE. DNA methylation-related chromatin remodeling in activity-dependent BDNF gene regulation. Science 2003(5646):302:890-3.

[47] Itoh M, Ide S, Takashima S, Kudo S, Nomura Y, Segawa M, Kubota T, Mori H, Tanaka S, Horie H, Tanabe Y, Goto Y. Methyl CpG-binding protein 2 (a mutation of which causes Rett syndrome) directly regulates insulin-like growth factor binding protein 3 in mouse and human brains. J Neuropathol Exp Neurol 2007:66(2):117-23.

[48] Miyake K, Hirasawa T, Soutome M, Itoh M, Goto Y, Endoh K, Takahashi K, Kudo S, Nakagawa T, Yokoi S, Taira T, Inazawa, J, Kubota T. The protocadherins, PCDHB1 and PCDH7, are regulated by MeCP2 in neuronal cells and brain tissues: implication for pathogenesis of Rett syndrome. BMC Neurosci 2011;12:81.

[49] Chahrour M, Jung SY, Shaw C, Zhou X, Wong ST, Qin J, Zoghbi HY. MeCP2, a key contributor to neurological disease, activates and represses transcription. Science 2008, 320(5880):1224-1229.

[50] Kubota T, Aradhya S, Macha M, Smith AC, Surh LC, Satish J, Verp MS, Nee HL, Johnson A, Christan SL, Ledbetter DH. Analysis of parent of origin specific DNA methylation at SNRPN and PW71 in tissues: implication for prenatal diagnosis. J Med Genet. 1996 Dec;33(12):1011-4.

[51] Fombonne E. Epidemiology of pervasive developmental disorders. Pediatr Res 2009;65(6):591-8.

[52] Ma DK, Jang MH, Guo JU, Kitabatake, Y, Chang ML, Pow-Anpongkul N, et al. Neuronal Activity-Induced Gadd45b Promotes Epigenetic DNA Demethylation and Adult Neurogenesis. Science 2009;323(5917):1074-7.

[53] McGowan PO, Sasaki A, D'Alessio AC, Dymov S, Labonté B, Szyf M, Turecki G, Meaney MJ. Epigenetic regulation of the glucocorticoid receptor in human brain associates with childhood abuse. Nat Neurosci 2009;12(3):342-8.

[54] Murgatroyd C, Patchev AV, Wu Y, Micale V, Bockmühl Y, Fischer D, Holsboer F, Wotjak CT, Almeida OF, Spengler D. Dynamic DNA methylation programs persistent adverse effects of early-life stress. Nat Neurosci 2009;12(12):1559-66.

[55] Renthal W, Kumar A, Xiao G, Wilkinson M, Covington HE 3rd, Maze I, Sikder D, Robison AJ, LaPlant Q, Dietz DM, Russo SJ, Vialou V, Chakravarty S, Kodadek TJ, Stack A, Kabbaj M, Nestler EJ. Genome-wide analysis of chromatin regulation by cocaine reveals a role for sirtuins. Neuron 2009;62(3):335-48.

[56] Pascual M, Boix J, Felipo V, Guerri C. Repeated alcohol administration during adolescence causes changes in the mesolimbic dopaminergic and glutamatergic systems and promotes alcohol intake in the adult rat. J Neurochem 2009;108(4):920-31.

[57] Gluckman PD, Seng CY, Fukuoka H, Beedle AS, Hanson MA. Low birthweight and subsequent obesity in Japan. Lancet 2007;369(9567):1081-2. 
[58] Painter RC, de Rooij SR, Bossuyt PM, Simmers TA, Osmond C, Barker DJ, Bleker OP, Roseboom TJ. Early onset of coronary artery disease after prenatal exposure to the Dutch famine. Am J Clin Nutr 2006;84(2):322-7.

[59] St Clair D, Xu M, Wang P, Yu Y, Fang Y, Zhang F, Zheng X, Gu N, Feng G, Sham P, He L. Rates of adult schizophrenia following prenatal exposure to the Chinese famine of 1959-1961. JAMA 2005;294(5):557-62.

[60] Silveira PP, Portella AK, Goldani MZ, Barbieri MA. Developmental origins of health and disease (DOHaD). J Pediatr (Rio J) 2007;83(6):494-504.

[61] Lillycrop KA, Phillips ES, Torrens C, Hanson MA, Jackson AA, Burdge GC: Feeding pregnant rats a protein-restricted diet persistently alters the methylation of specific cytosines in the hepatic PPAR alpha promoter of the offspring. Br J Nutr 2008;100(2): 278-82.

[62] Tobi EW, Lumey LH, Talens RP, Kremer D, Putter H, Stein AD, et al. DNA methylation differences after exposure to prenatal famine are common and timing-and sexspecific. Hum Mol Genet 2009;18(21):4046-53.

[63] Lim D, Bowdin SC, Tee L. Clinical and molecular genetic features of Beckwith-Wiedemann syndrome associated with assisted reproductive technologies. Hum Reprod 2009; 24(3):741-7.

[64] Bliek J, Alders M, Maas SM, Oostra RJ, Mackay DM, van der Lip K, et al. Lessons from BWS twins: complex maternal and paternal hypomethylation and a common source of haematopoietic stem cells. Eur J Hum Genet 2009;17(12):1625-34.

[65] Basic investigation report for handicapped children 2005 (in Japanese). http:// www.mhlw.go.jp/toukei/saikin/hw/titeki/index.html (Sep 9; 2013).

[66] Yeargin-Allsopp M, Rice C, Karapurkar T, Doernberg N, Boyle C, Murphy C. Prevalence of autism in a US metropolitan area. JAMA. 2003;289(1):49-55.

[67] Holden C. Autism Now. Science 2009;323:565.

[68] Fombonne E. Epidemiology of pervasive developmental disorders. Pediatr Res 2009;65(6):591-8.

[69] Kim YS, Leventhal BL, Koh YJ, Fombonne E, Laska E, Lim EC, et al. Prevalence of autism spectrum disorders in a total population sample. Am J Psychiatry 2011;168(9): 904-12.

[70] Lord C. Epidemiology: How common is autism? Nature 2011;474(7350):166-8.

[71] Waterland RA, Jirtle RL. Transposable elements: targets for early nutritional effects on epigenetic gene regulation. Mol Cell Biol 2003;23(15):5293-300.

[72] Kucharski R, Maleszka J, Foret S, Maleszka R. Nutritional control of reproductive status in honeybees via DNA methylation. Science 2008;319(5871):1827-30. 
[73] Yaoi T, Itoh K, Nakamura K, Ogi H, Fujiwara Y, Fushiki S. Genome-wide analysis of epigenomic alterations in fetal mouse forebrain after exposure to low doses of bisphenol A. Biochem Biophys Res Commun 2008;376(3):563-7.

[74] Gore AC, Walker DM, Zama AM, Armenti AE, Uzumcu M. Early life exposure to endocrine-disrupting chemicals causes lifelong molecular reprogramming of the hypothalamus and premature reproductive aging. Mol Endocrinol 2011;25(12):2157-68.

[75] Kondo M, Gray LJ, Pelka GJ, Christodoulou J, Tam PP, Hannan AJ. Environmental enrichment ameliorates a motor coordination deficit in a mouse model of Rett syndrome-Mecp2 gene dosage effects and BDNF expression. Eur J Neurosci 2008;27(12): 3342-50.

[76] Lonetti G, Angelucci A, Morando L, Boggio EM, Giustetto M, Pizzorusso T. Early environmental enrichment moderates the behavioral and synaptic phenotype of MeCP2 null mice. Biol Psychiatry 2010;67(7):657-65.

[77] Nag N, Moriuchi JM, Peitzman CG, Ward BC, Kolodny NH, Berger-Sweeney JE. Environmental enrichment alters locomotor behaviour and ventricular volume in Mecp2 1lox mice. Behav Brain Res 2009;196(1):44-8.

[78] Kerr B, Silva PA, Walz K, Young JI. Unconventional transcriptional response to environmental enrichment in a mouse model of Rett syndrome. PLoS One 2010;5(7):e11534.

[79] Luikenhuis S, Giacometti E, Beard CF, Jaenisch R. Expression of MeCP2 in postmitotic neurons rescues Rett syndrome in mice. Proc Natl Acad Sci USA 2004;101(16): 6033-8.

[80] Guy J, Gan J, Selfridge J, Cobb S, Bird A. Reversal of neurological defects in a mouse model of Rett syndrome. Science 2007;315(5815):1143-7.

[81] Lioy DT, Garg SK, Monaghan CE, Raber J, Foust KD, Kaspar BK, et al. A role for glia in the progression of Rett's syndrome. Nature 2011;475(7357):497-500.

[82] Vecsler M, Simon AJ, Amariglio N, Rechavi G, Gak E. MeCP2 deficiency downregulates specific nuclear proteins that could be partially recovered by valproic acid in vitro. Epigenetics 2010;5(1):61-7.

[83] Abel T, Zukin RS. Epigenetic targets of HDAC inhibition in neurodegenerative and psychiatric disorders. Curr Opin Pharmacol. 2008;8(1):57-64.

[84] Cassel S, Carouge D, Gensburger C, Anglard P, Burgun C, Dietrich JB, Aunis D, Zwiller J. Fluoxetine and cocaine induce the epigenetic factors MeCP2 and MBD1 in adult rat brain. Mol Pharmacol. 2006;70(2):487-92.

[85] Popp C, Dean W, Feng S, Cokus SJ, Andrews S, Pellegrini M, et al. Genome-wide erasure of DNA methylation in mouse primordial germ cells is affected by AID deficiency. Nature 2011;463(7284):1101-5. 
[86] Daxinger L, Whitelaw E. Transgenerational epigenetic inheritance: more questions than answers. Genome Res 2010;20(12):1623-8.

[87] Horsthemke, B. Heritable germline epimutations in humans. Nat Genet 2007;39(5): 573-4.

[88] Chong S, Youngson NA, Whitelow E. Heritable germline epimutation is not the same as transgenerational epigenetic inheritance. Nat Genet 2007;39(5):574-5.

[89] Rakyan VK, Chong S, Champ ME, Cuthbert PC, Morgan HD, Luu KV, WhitelawE. Transgenerational inheritance of epigenetic states at the murine Axin(Fu) allele occurs after maternal and paternal transmission. Proc Natl Acad Sci USA 2003;100(5): 2538-43.

[90] Relton CL, Davey Smith G. Two-step epigenetic Mendelian randomization: a strategy for establishing the causal role of epigenetic processes in pathways to disease. Int J Epidemiol 2012;41(1):161-76.

[91] Kappeler L, Meaney MJ. Epigenetics and parental effects. Bioessays 2010;32(9): 818-27.

[92] Waterland RA, Travisano M, Tahiliani KG. Diet-induced hypermethylation at agouti viable yellow is not inherited transgenerationally through the female. FASEB J. 2007;21(12):3380-5.

[93] Anway MD, Cupp AS, Uzumcu M, Skinner MK. Epigenetic transgenerational actions of endocrine disruptors and male fertility. Science 2005;308(5727):1466-9. Erratum in: Science 2010;328(5979):690.

[94] Manikkam M, Tracey R, Guerrero-Bosagna C, Skinner MK. Plastics derived endocrine disruptors (BPA, DEHP and DBP) induce epigenetic transgenerational inheritance of obesity, reproductive disease and sperm epimutations. PLoS One 2013;8(1):e55387.

[95] Seong KH, Li D, Shimizu H, Nakamura R, Ishii S. Inheritance of Stress-Induced, ATF-2-Dependent Epigenetic Change. Cell 2011;145(7):1049-61.

[96] Champagne FA, Weaver IC, Diorio J, Dymov S, Szyf M, Meaney MJ. Maternal care associated with methylation of the estrogen receptor-alpha1b promoter and estrogen receptor-alpha expression in the medial preoptic area of female offspring. Endocrinology 2006;147(6):2909-15.

[97] Crews D, Gillette R, Scarpino SV, Manikkam M, Savenkova MI, Skinner MK. Epigenetic transgenerational inheritance of altered stress responses. Proc Natl Acad Sci USA 2012;109(23):9143-8.

[98] Becker C, Weigel D. Epigenetic variation: origin and transgenerational inheritance. Curr Opin Plant Biol 2012;15(5):562-7. 
[99] Rakyan V, Whitelaw E. Transgenerational epigenetic inheritance. Curr Biol 2003;13(1):R6.

[100] [100] Schmitz RJ, Schultz MD, Lewsey MG, O'Malley RC, Urich MA, Libiger O, Schork NJ, Ecker JR. Transgenerational epigenetic instability is a source of novel methylation variants. Science 2011;334(6054):369-73.

[101] Zocchi L, Sassone-Corsi P. Joining the dots: from chromatin remodeling to neuronal plasticity. Curr Opin Neurobiol 2010;20(4):432-40.

[102] Lister R, Mukamel EA, Nery JR, Urich M, Puddifoot CA, Johnson ND, et al. Global epigenomic reconfiguration during mammalian brain development. Science 2013;341(6146):1237905.

[103] Crews D, Gillette R, Scarpino SV, Manikkam M, Savenkova MI, Skinner MK. Epigenetic transgenerational inheritance of altered stress responses. Proc Natl Acad Sci USA 2012;109(23):9143-8.

[104] Ng SF, Lin RC, Laybutt DR, Barres R, Owens JA, Morris MJ. Chronic high-fat diet in fathers programs $\beta$-cell dysfunction in female rat offspring. Nature 2010;467(7318): 963-6.

[105] Ferguson-Smith AC, Patti ME. You are what your dad ate. Cell Metab 2011;13(2): 115-7.

[106] Law JA, Du J, Hale CJ, Feng S, Krajewski K, Palanca AM, Strahl BD, Patel DJ, Jacobsen SE. Polymerase IV occupancy at RNA-directed DNA methylation sites requires SHH1.Nature 2013;498(7454):385-9.

[107] Konermann S, Brigham MD, Trevino AE, Hsu PD, Heidenreich M, Cong L, Platt RJ, Scott DA, Church GM, Zhang F. Optical control of mammalian endogenous transcription and epigenetic states. Nature 2013;500(7463):472-6. 